\title{
Comprensión lectora apoyada en la taxonomía de Bloom: Búsqueda del desarrollo del pensamiento crítico en universitarios
}

\section{Reading comprehension supported by Bloom's taxonomy: Search for the development of critical thinking in university students}

\author{
MSc. Jordán Alba $\mathrm{R}^{1}$ \\ albajordan83@hotmail.com \\ Parrales Carmen $\mathrm{S}^{2}$ \\ susycaph@yahoo.com \\ Sarah Iza \\ sj.iza@uta.edu.ec
}

Recibido: 1/07/2018, Aceptado: 1/09/2018

\section{RESUMEN}

Partiendo de la meta de la educación para desarrollar los puntos de vista de los estudiantes y teniendo en cuenta que la comprensión lectora es una parte esencial del proceso de enseñanza-aprendizaje, esta investigación tuvo como objetivo determinar la influencia de la lectura en el desarrollo de las habilidades de pensamiento crítico. Se evidenciaron dificultades en los resultados de aprendizaje y procesos de los estudiantes A2 en el Centro de Idiomas de la Universidad Técnica de Ambato. Para satisfacer las necesidades de estos estudiantes, se realizó un estudio para definir adecuadamente las variables, su marco teórico y el enfoque de investigación adecuado de acuerdo con un paradigma crítico proactivo. En este estudio también se incluyeron las técnicas de análisis y recolección de datos. La metodología de investigación utilizada fue cualitativa y cuantitativa en su alcance. A partir de esto, se diseñó una propuesta para ayudar a resolver los problemas de comprensión lectora en el idioma inglés mediante la promoción de un proceso controlado de lectura que permita desarrollar el pensamiento crítico. Se diseñó un folleto de lecturas con actividades didácticas y calificadas, basadas en los niveles de la taxonomía de Bloom para fomentar los hábitos de lectura y el entrenamiento del pensamiento para poder discernir y evaluar la información.

\footnotetext{
1 Universidad Técnica de Ambato. Ecuador

2 Universidad Técnica de Ambato. Ecuador

3 Universidad Técnica de Ambato. Ecuador
} 


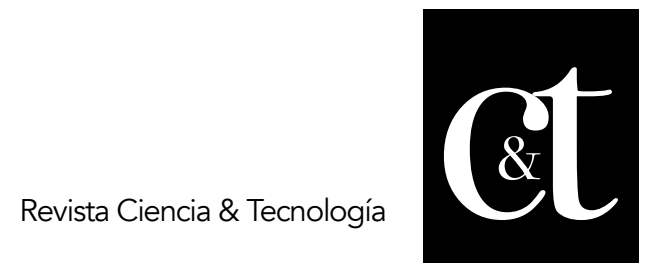

No. 20, 31 de octubre de 2018

ISSN impreso: 1390 - 6321

Palabras clave: comprensión lectora, destrezas de lectura, estrategias de lectura, pensamiento crítico

\begin{abstract}
Starting from the goal of education to develop student's viewpoints and considering that reading comprehension is an essential part of the teaching- learning process, this research aimed to determine the influence of reading on the development of critical thinking skills. Difficulties were evidenced in the learning results and processes of A2 students in the Language Center of the Technical University of Ambato. To meet these students' needs, a study was carried out to adequately define the variables, their theoretical framework and the appropriate research approach according to a proactive critical paradigm. In this study the analysis and data collection techniques were included as well. The research methodology used was qualitative and quantitative in its scope. From this, a proposal was designed to help solve the problems in reading comprehension in English through the promoting of a controlled process of reading that allows for critical thinking to be developed. A booklet of readings was designed with didactic and graded activities based on the levels of Bloom's taxonomy to encourage reading habits and thought training to be able to discern and evaluate information.
\end{abstract}

Keywords: critical thinking, reading comprehension, reading skills, reading strategies.

\title{
Introduction
}

Currently, education has taken a new approach based on the contributions of cognitive sciences. Thus, it has stopped conceiving learning as a compendium of declarative knowledge and given way to training for skills and competences. It is from this conception of education as a formative training centered on three elements. These being the development of being, doing and know-how in context, which adds to the mastery of the higher cognitive abilities in Reading Comprehension and Critical thinking. Reading Comprehension constitutes one of the fundamental pillars for the acquisition of knowledge and development of competences in the formative processes of the students.

There is a consensus that reading as a metacognitive process constitutes an act of complex order, whose development is facilitated if the student has information and prior knowledge of its nature, processes, purposes, techniques and strategies. The foundation of the relevance of the study of reading comprehension and its relationship to critical thinking in higher education contexts lies in the fact that nowadays it is a transversal need to train students to be capable of thinking critically. This is not only about academic contents, it includes daily life and society problems. The promotion of experiences that stimulate the exercise of critical thinking is fundamental at present. In a world where access to information is no longer a problem, it is focused on an ethical assessment of the information found.

The development of this thesis has several chapters that analyzes each of the techniques and strategies. This is of great importance because it demonstrates these as easy strategies to study and apply. Making it easier for teachers to add these activities into their daily lesson. This proposal includes some sample readings that can be used by the teachers who believe that they do not have sufficient time to 


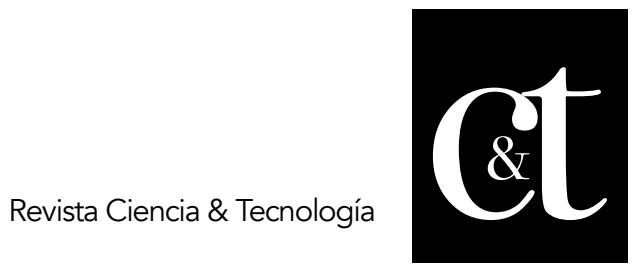

No. 20, 31 de octubre de 2018

ISSN impreso: 1390 - 6321

prepare the material themselves. Besides outlining the techniques and strategies that can be used to adapt their own material to accomplish these goals.

Lecture

Several authors agree that reading is one of the mental abilities that needs to go hand in hand with understanding, this allows to organize, arguments, ideas, imagination, opinions and other aspects that complement previous experiences and concepts already known. With this, it is defined to read as the ability to understand, develop mental and cognitive skills in the process, make inferences conjugating previous experiences and what is being read. Reading is also an interaction between the text and the reader, with which the reader is expected to enjoy what he is reading. Finally, reading is known as the gateway to knowledge, creativity, imagination and innovation, characteristics that also form a critical thinker (Solé, 1998; Fairbairn \& Fairbairn, 2001; Guerrero 2016).

\section{Importance}

Reading is considered an important and useful activity that human beings should practice. Reading promotes the development of knowledge, reasoning, and value judgments, tending to significantly develop interpersonal communication skills, thus creating the possibility of maintaining and improving reflective habits. To learn to read, it takes time, because it is a successive and progressive process. Performing this activity allows the mind to be exercised, while at the same time helping to develop listening, speaking and linguistic capacities in general. Reading helps individuals focus on what another person is trying to communicate or transmit through a text (Fairbairn \& Fairbairn, 2001; Calderon \& Slakk, 2018).

Levels of lecture

Some authors argue about levels and start with the programming of the meaning of a single word as the most elemental form of comprehension. According to Sánchez (2013), mentioned as a recommendation, that readers must extract the meaning of a phrase or a complete idea, focus on a single word makes many times you lose the meaning of the phrase that was being analyzed. Therefore, the author mentions the paramount importance in a complete idea, over the word that is not clearly understood.

The success of understanding a reading also depends a lot on the previous knowledge that the reader has, his capacity for inference and his appreciation of the text, besides that, it is necessary to give him the focus that the reading needs, that is, if the reading is doing for a specific study process, by general knowledge or if you want to carry out a research project.

In the process of understanding there are different procedures that can be classified into the following levels:

Literacy level. It is the reader's ability to remember ideas and information that are directly stated in the textbook material. We only focus on deciphering the words in the text without any other aspect of deduction or analysis (Sánchez, 2013).

Inferential level. It is the reader's ability to extract ideas and information not directly stated in the textbook material, using prior or background knowledge to assist in such 


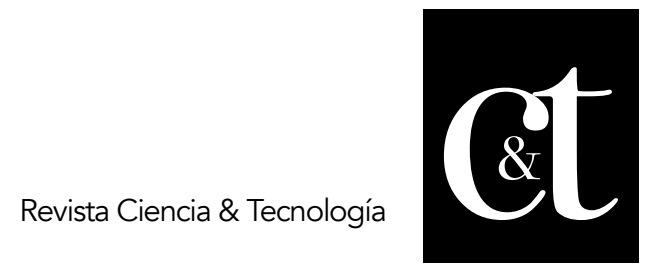

No. 20, 31 de octubre de 2018

ISSN impreso: 1390 - 6321

understanding. This level has an intimate relationship with cognitive processes like abstraction, analysis, and deduction amongst others, which are important for its development (Sánchez, 2013).

Critical comprehensive. It is the reader's ability to respond with personal judgments and ideas about the content of the textbook material, using his or her past knowledge and thoughts on the subject (Sánchez, 2013).

\section{Reading Stages}

One of the things to bear in mind when lesson planning is that classroom reading is not the same as real reading. Classroom reading aims at helping students develop the skills they need to read more effectively in a variety of ways To enable this we plan 'pre-reading', 'while-reading', and 'post-reading' stages. These stages can help us make reading more communicative).

Pre-Reading is the stage that allows for the generation of interest in the text to be read. During this stage there is a review of previous knowledge and prerequisites. These are acquired within the environment of the previous studies of the students. The pre-requisites give students the formal education needs such as: vocabulary, notions of their reality and use of language. In addition, it is an opportunity to motivate and generate curiosity. Moreover, teachers should encourage students to come out with their own questions, statements, or hypotheses rather than answering given questions which dictate a way of reading the texts (Abd, Subk, Ahmad, \& Ismail, 2014).

During-Reading is the stage where the strategies that favor understanding and the step to enjoy reading in the written text, savor the content and consequently the easy assimilation of the text is used. It can be silent, oral, individual, or group reading. Various techniques are used such as: flannel graphs, albums, puppets, among others. Furthermore, teachers need to be creative enough to devise the reading tasks which could offer students to "read, the text in many ways (Abd, Subk, Ahmad, \& Ismail, 2014).

Post-Reading is the stage that is at the end of the process. It is done as support to deepen understanding. It is the time that reading comprehension exercises and learning of values through activities are done. This is to encourage understanding, interpretation, creation and/or extension of the reading material. Activities are directed to the application of content in other contexts and to maintain the interest of the message from the beginning to the end of the process and if possible a little further. Teachers could carry out activities which help students to think critically on other ways in which the topic of the reading text could have been written about (Abd, Subk, Ahmad, \& Ismail, 2014).

Reading strategies

Reading strategies are conscious plans sets of steps that good readers use to make sense of text. Reading strategy instruction helps students become purposeful, active readers who are in control of their own reading comprehension.

These strategies have research-based evidence for improving text comprehension. 


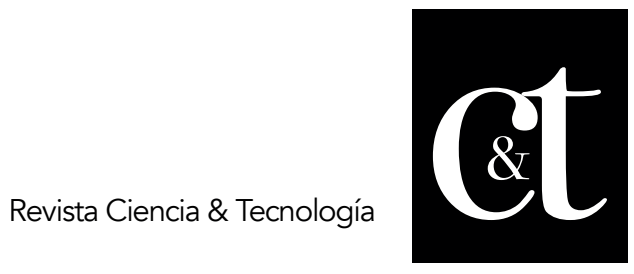

No. 20, 31 de octubre de 2018

ISSN impreso: 1390 - 6321

Furthermore, reading strategies are the mental actions done during reading that improve comprehension. These strategies are there to help readers overcome difficulties in understanding the reading. The implementation of reading strategies can be on an individual level or in combination. Furthermore, the approaches are chosen because they are deemed to be the most effective for students. A variety of the reading strategies are summarized below (Kucukoglu, 2013).

Activating prior knowledge. Activating prior knowledge is a reading strategy that occurs before the student is introduced to reading material. Pre-reading activities are use. Some of these are journals or class discussion which enable the reader to make connections between something they already have knowledge of and the new knowledge from the text (Kucukoglu, 2013).

Questioning. Students develop and attempt to answer questions about the important ideas in the text while reading, using words such as "where" or "why" to develop their questions (Kucukoglu, 2013).

Visualization. This is where a mental image is developed of what is being described in the text. This will help in the recall of the information of the text. A sample activity to promote this strategy involves students examining objects placed in front of them. Later, they look carefully at a picture that depicts a scene. Finally, the teacher removes the objects and picture, and then asks students to visualize and describe what they saw (Kucukoglu, 2013).

Drawing Inferences. This is when students generate information that not explicitly stated in the text. This requires students looking for key words and demonstrating how they can draw inferences from these words. This needs to be model by teachers so that students learn how this process is done (Kucukoglu, 2013).

Summarizing/Retelling. Students briefly describe, orally or in writing, the main points of what they read in their own words. This can be done with a partner or teacher. If students are having trouble with this activity, their partner or teacher can prompt them with questions like "What comes next?" or "What else did the passage say about [subject]?" (Kucukoglu, 2013).

Reading comprehension

Educational demands currently make the teachers classroom practice oriented towards following the guidelines provided by education; and in this manner the topic of reading comprehension is established as one of the priorities in their development by use of efficient and pertinent pedagogic strategies to counteract the dip compared to other regions of the continent. Reading is without a doubt an implicit way of communicating with the world, it develops intellectual, affective, communicational and other capacities in human beings that assist them in the environment in which they unfold throughout their lives (Hansen, 2016).

Reading comprehension refers to the ability that some individuals possess, and allows them to understand what they are reading, meanings of words explicitly or infer implicit ideas from the text. Understanding reading is one of the most significant elements in learning a new language, because it is the basis to start with this process. Reading is an important activity and is a means to expand the knowledge of language 


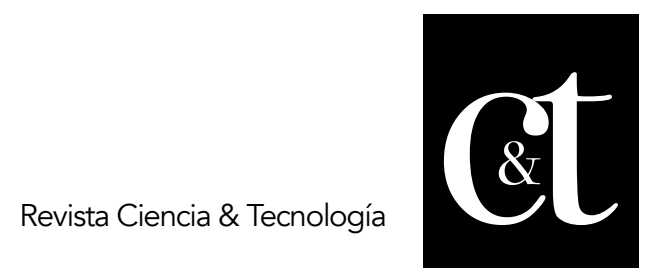

No. 20, 31 de octubre de 2018

ISSN impreso: 1390 - 6321

students. Reading is considered a valuable skill in language learning (Schaefer \& Michalopoulou, 2015; Nemat Tabrizi \& Jafari, 2015).

Sub skills of reading

Secondary reading skills play a very important role in the learning process of people, as they help to activate existing knowledge, thus creating a mindset that new knowledge and ideas can join. For Douglas (2001), this mentality is based on the following skills that are classified as follows:

Reading for specific information or scanning: This sub-skill allows you to locate information quickly because not all the text is read.

Reading for gist or Skimming: This sub skill can read the text quickly in order to get the general idea to know what the text itself is.

Reading for detail: This sub-skill allows the reader to take longer par focus on what you are looking for.

Critical thinking learning process

Learning is subject to change permanently, it plays an important role in human behavior, reflects whether or not there is acquisition of skills or knowledge that are only obtained through practice exclusively study, observation and / or instruction.

With the passage of time we have seen the need to develop critical thinking skills in students. These skills will allow them to perform as active entities within their work space such as classrooms and from there consolidate their critical development in society itself. The society demands a critical and prospective being that is framed in critical pedagogy established within the curricular actualization and strengthening of general basic education.

According to Vaseghi, Gholami, \& Barjesteh (2012), critical thinking is a directed and self- disciplined thought that makes logical relationships that help the development of its autonomous rationality. The main characteristic of this thought is the intellectual autonomy that everybody has.

Learning level

Bloom's Revised Taxonomy in 2001. Key to this is the use of verbs rather than nouns for each of the categories and a rearrangement of the sequence within the taxonomy. They are arranged below in increasing order, from lower order to higher order. 


\section{Bloom's Taxonomy (Revised)}

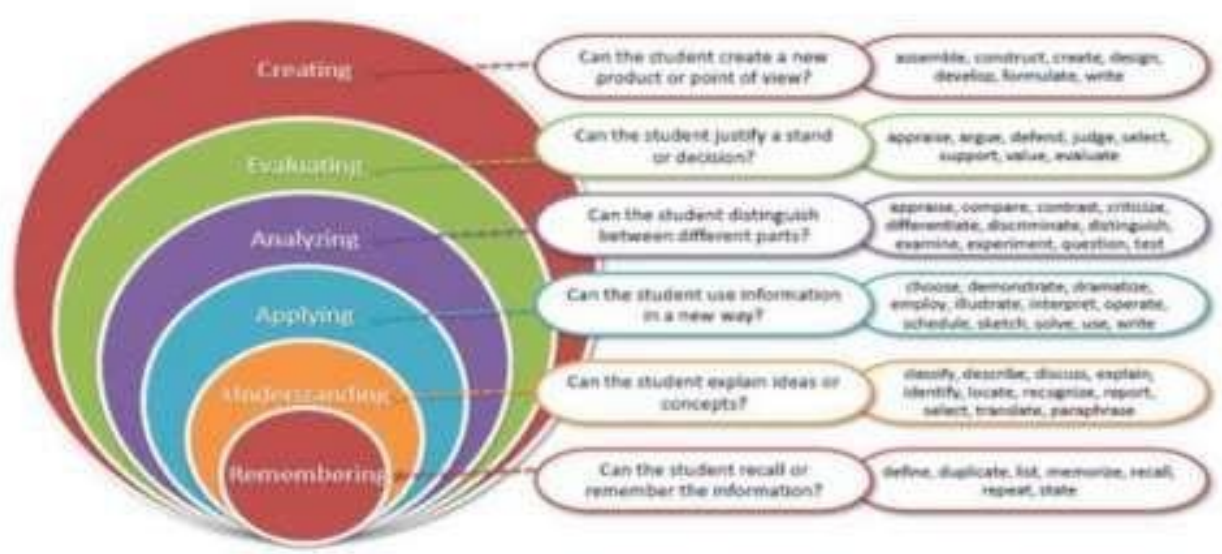

Figure 1. Bloom 's Taxonomy (revised)

Source: Adapted from Bloom in 2001

\begin{tabular}{|c|c|}
\hline Lower-Order Thinking Skills & Higher-Order Thinking Skills \\
\hline 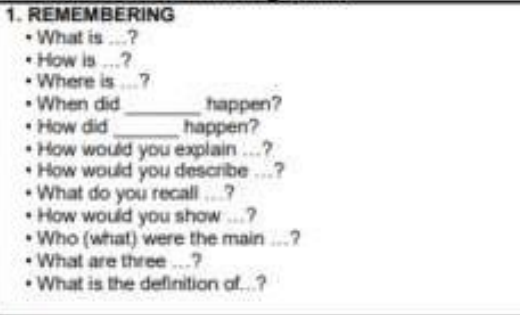 & 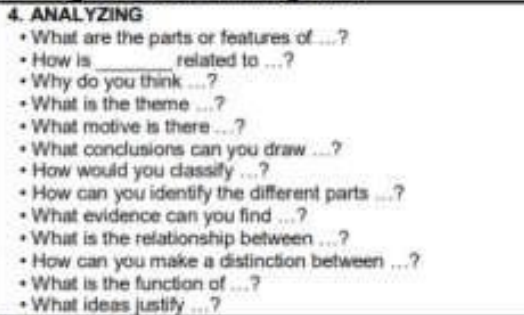 \\
\hline 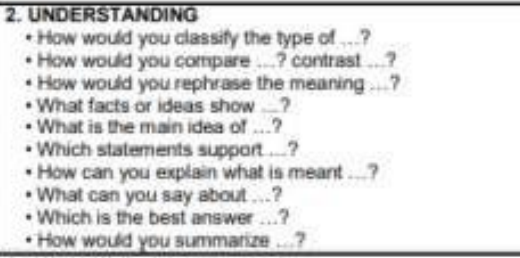 & 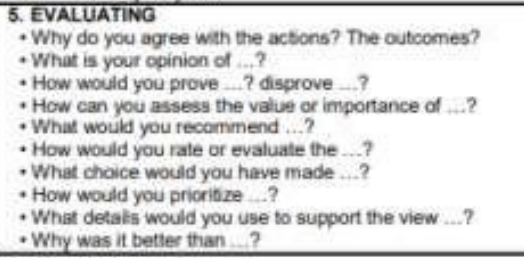 \\
\hline 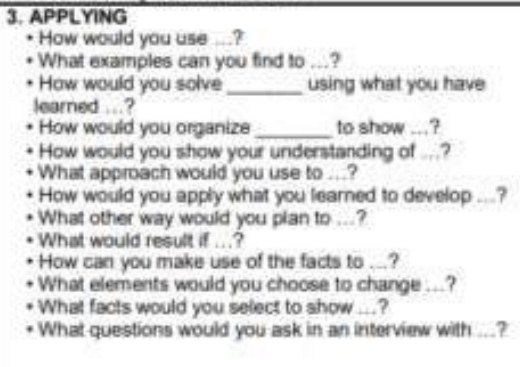 & 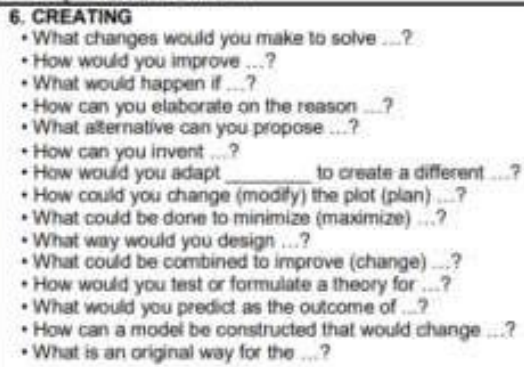 \\
\hline
\end{tabular}

Figure 2. Cue questions based on Blooms' Taxonomy of critical thinking Source: Adapted from Bloom in 2001 


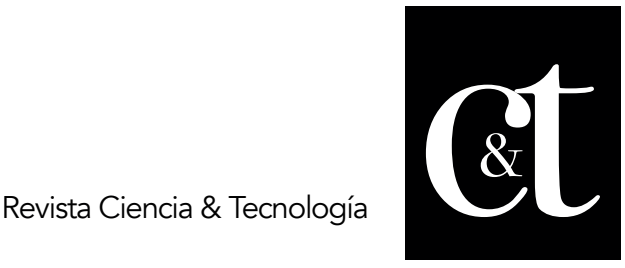

No. 20, 31 de octubre de 2018

ISSN impreso: 1390 - 6321

\section{Importance}

According to Fernández and Mayorga (2015), the importance of developing critical thinking lies in the development of individual capacities in each person so that they can propose their own criteria and to help mitigate any type of difficulty they may face, by use of various strategies or cognitive processes, in relation to the daily events in their environment.

In addition, it improves communication, which is done in a clearer and more efficient way, promoting free expression in a clear, precise and cordial communication framework, avoiding confusion and misinterpretation. The correct construction of arguments not only gives the capacity to form valid ideas, but the ability to transmit them in a more assertive way and for this reason it is said that thought is inseparably joined to language, because it is an indispensable requisite for the formation of thought and is also a medium to reflect thoughts (Becerril, Talavera, Gómez and Rojas, 2017).

\section{Strategies for critical thinking}

Critical thinking for Huang, Lindell, Jaffe, \& Sullivan (2016), is described as disciplined thinking that is clear, rational, open minded, and informed by evidence. This is often used to describe the ability of professionals, today there is a strong feeling that this ability is fading. Following are strategies that will help the growth of critical thinking skills: 1) Be a continuous learner; 2) Make the right decision for the majority; 3) Listen and consider unconventional opinions; 4) Avoid analysis paralysis; 5) Analyze yourself.

\section{Methodology}

This research will be based in particular on a qualitative and quantitative approach because it will be carried out in the scene interpreting and analyzing this problem that is in this educational community. It is called quantitative, because it will gather information in quantifiable data, this information is subjected to a statistical analysis and uses indicators that evaluate how this affects Bloom's taxonomy in the development of reading skills and critical thinking. In addition, it uses a qualitative approach, called in this way because it applies surveys, it investigates statistical indexes that contain a value judgment with respect to the viability of the research work.

This research is field because it was conducted in the place where the research problem occurred. Research techniques are applied to gather information such as observation, interview, survey to those involved in this problem, obtaining in this way as a previous information that was obtained directly, truthfully, authentically, in the place of the facts. In addition, the development of bibliographic and documentary research includes different approaches, theories, conceptualizations and criteria of different authors on a given subject, based on documents, or in books, magazines, newspapers and other publications to study the two variables of purpose of this investigation.

\section{Population and sample}

The population for the present study consists of the teachers and students of the elementary level A2 at Universidad Tecnica de Ambato in the Language Center. The total population is formed by 10 teachers and 240 students who are struggling in this 
level.

\section{Sample}

For Sánchez and Fuentes (2016), the sample is a subset of cases or individuals of a statistical population. Basically, it is a representative part of the population. Considering that for the current study the population of teachers is finite or small, it will not be considered a sample but rather as a whole population. While the students is a larger population from which a sample can be taken using the following calculation.

$n=$ ? (Sample size)

$n c=95 \%$ (confident margin) $=1,96$

$p=0,5$ probability of success, which is $50 \%$

$q=0,5$ probability of failure, which is $50 \%$

$m e=0,05$ (error margin)

$\mathcal{N}=240$ (population size)

$$
\begin{aligned}
& n=\frac{\mathcal{N}}{1+(\mathcal{N})(m e)^{2}} \\
& n=\frac{248}{1+(240)(0.05)^{2}} \\
& n=\frac{248}{1+(240)(0,0025)} \\
& n=\frac{248}{1+(0,60)} \\
& n=\frac{248}{1.60} \\
& n=150
\end{aligned}
$$

Instruments

A structured questionnaire was applied, for Hernández-Sampieri and Mendoza (2018) the questionnaire "consists of a group of questions regarding one or more variables to be measured. It must be congruent with the approach of the problem and hypothesis "(p.250).

With the aforementioned, the research is based on a bank of 10 questions made by the researcher, addressed to 150 students, and another bank of 10 questions addressed to 10 teachers of the elementary level A2 at the Technical University of Ambato in the Language Center.

\section{Results}

Below, the most relevant results of the investigation are presented. 


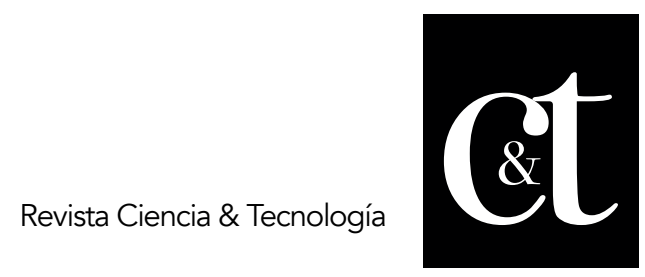

No. 20, 31 de octubre de 2018

ISSN impreso: 1390 - 6321

\section{Students}

In the survey applied to students, question number 6 is the most representative and shows that there is a low level of development of reading comprehension in $A 2$ students of the Language Center of the Technical University of Ambato, as both teachers and Students apply the strategies in the classroom and practice them sporadically. Therefore, students sometimes have a limited capacity to understand a text through the assimilation of some aspects, such as the message of the text, the main idea or secondary ideas and the meaning of words or phrases, among other aspects. They clearly reflect.

Question 6. When you read, do you understand the ideas before, during and at the end of a text?

Table 1. Global results in question 6

\begin{tabular}{|l|c|c|}
\hline Alternatives & $\begin{array}{c}\text { People } \\
\text { (Students) }\end{array}$ & Porcentage \\
\hline Always & 19 & $13 \%$ \\
\hline Sometimes & 129 & $86 \%$ \\
\hline Never & 2 & $1 \%$ \\
\hline Total & 150 & $\mathbf{1 0 0} \%$ \\
\hline
\end{tabular}

Source: Field research

Out of 150 students the $13 \%$ of students always have a global understanding of an English text, $86 \%$ of students that correspond 134 students sometimes understand. And $1 \%$ of students never understand the complete text.

The data shows that around $87 \%$ of the students do not understand the ideas before, during and at the end of a text. This is something that teachers need to work on guided reading for getting a complete comprehension.

\section{Professors}

In this section it is evident that students have a low level of critical thinking development, this is reflected in question 8 , especially when they have to express their points of view, when discussing or giving their conclusions about the text in which they reflect his thought. In the same way, only occasionally students put into practice strategies that develop critical thinking, showing the irregularity that exists between classroom strategies and the development of critical thinking.

Question 8. Are your students able to analyze and be critical in a reading comprehension task? 
Table 2. Global results in question 8

\begin{tabular}{|l|c|c|}
\hline Alternatives & $\begin{array}{c}\text { People } \\
\text { (Students) }\end{array}$ & Porcentage \\
\hline Always & 0 & $0 \%$ \\
\hline Sometimes & 10 & $100 \%$ \\
\hline Never & 0 & $0 \%$ \\
\hline Total & $\mathbf{1 0}$ & $\mathbf{1 0 0} \%$ \\
\hline
\end{tabular}

Source: Field research

\section{Relation}

It is established that the relationship between reading comprehension and the development of critical thinking is directly linked. Unfortunately, the processes that students manifest and manage in the comprehension of reading have not been the generators of the development of critical thinking because they are not applied in a systematic way. Nor do they have the strategies that accompany and encourage reading processes, in order to follow up and analyze the text in full dimension.

\section{Conclusion}

It is clearly evident that students have great difficulty in understanding the text they read, whether at the beginning, in the development or at the end, the conception of implicit aspects, the main or secondary ideas, the final message, the meaning of unknown words. They are easily assimilated in the context. That is to say, students of level A2 of the Language Center of the Technical University of Ambato have a limited capacity to understand and be critical of the readings they perform.

In addition, it was concluded that the critical thinking that students possess is relatively low, this is reflected when students must express a value judgment, when expressing their points of view, or simply when discussing when they conclude a text. Rarely do students put into practice strategies to develop critical thinking. In fact, the teachers who were evaluated agree that only sometimes their students can analyze and be critical in a task of reading comprehension.

Finally, a close relationship was established according to the evaluations made, between the comprehension of the readings and the development of critical thinking of the students. Although according to the study carried out, it is concluded that students and teachers do not promote reading in a systematic and periodic way in the teaching - learning process. In addition, there are no playful strategies that support this learning process of students of A2 level of the Language Center of the Technical University of Ambato.

\section{Bibliographic references}

Abd Kadir, N., Subk, R., Ahmad Jamal, F. H., \& Ismail, J. (2014). The importance of teaching critical reading skills. University Technology MARA (UJTM). Pahang, Malaysia, 217.

Becerril, L. C., Talavera, B. E. M., Gómez, B. A. and Rojas, A. M. (2017). Desarrollo del pensamiento reflexivo y crítico en estudiantes de enfermería: Evidencia de una universidad pública mexicana. Revista Uruguaya de Enfermería, 12(1).

Calderon, M. E., \& Slakk, S. (2018). Teaching Reading to English Learners, Grades 


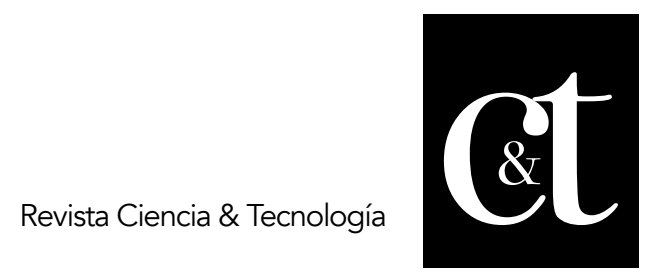

No. 20, 31 de octubre de 2018

ISSN impreso: 1390 - 6321

6-12: A Framework for Improving Achievement in the Content Areas. Corwin Press.

Douglas, B. H. (2001). Teaching by Principles and Interactive Approach to Language Pedagody. New York: Longman.

Fairbairn, G., \& Fairbairn, S. (2001). Reading at University a guide for students. Buckingham, Philadelphia: Open University Press.

Fernández de Morgano, N. Y. and Mayorga Pernia, C. A. (2015). Pensamiento Crítico y Comprensión de la Lectura en un curso de Inglés como lengua Extranjera. Ikala, 17,18 .

Hansen, E. J. (2016). Reading comprehension. Hansen: Avdelingf or økonomi, s pråk og samfunnsfag.

Hernández-Sampieri, R. and Mendoza, P. (2018). Metodología de la investigación: las rutas cuantitativa, cualitativa y mixta. McGraw-Hill Education.

Huang, G. C., Lindell, D., Jaffe, L. E., \& Sullivan, A. M. (2016). A multi-site study of strategies to teach critical thinking: 'why do you think that?'. Medical education, $50(2), 236-249$.

Kucukoglu, H. (2013). Improving reading skills through effective reading strategies. Procedia - Social and Behavioral Sciences 70:709-714.

Nemat Tabrizi, A. R., \& Jafari, M. (2015). The relationship among critical thinking, self-efficacy, and Iranian EFL learners' reading comprehension ability with different proficiency levels. Academic Research International, 6(2), 412-427

Sánchez Salinas, O. A., and Fuentes Flores, C. M. (2016). El robo de vehículos y su relación espacial con el contexto sociodemográfico en tres delegaciones centrales de la Ciudad de México (2010). Investigaciones geográficas, (89), 107- 120.

Sánchez, H. (2013). La compresión lectora, base del pensamiento crítico. Horizonte de la Ciencia, 35, 36, 37.

Schaefer, B., \& Michalopoulou, L. (2015). Reading Comprehension among potitna Greek Students from the Former Soviet during upper elementary years. Arizona Working Papers inSLA and Teaching, 49.

Solé, I. (1998). Estrategias de lectura. Barcelona: Graó.

Vaseghi, R., Gholami, R., \& Barjesteh, H. (2012). Critical Thinking: An Influential Factor in Developing English Reading. Advances in Asian Social Science (AASS) Vol. 2, No. 1, 2012: 401-410.

\section{Annexes}

\section{Annex 1. Student Survey}


MAESTRFA EN LA ENSEX̃ANZA DEL IDIOMA INGLÉS COMO LENGUA EXTRANJER.A.

Survey Directed to Strideats of the Languagn Center at Uaiversidad Tecnica de Ambato, of the A2 Elementary Level.

Objective: To determine the inflence of reading comprebension to develog critical thinking Intructions: Read carefully the followine questions and tek the best option

\section{STIDENT SLRVES}

1. How often do you extra resding activities in Englueb elass?

$\square$ Always $\square$ Sometimes $\square$ Never

2. When I read a text in English I understand it

$\square$ Always $\square$ Sounetimes $\square$ Never

3. I need illustranous and taties to help me figure out what a text is about $\square$ Always $\square$ Sometimes $\square$ Never

4. When I don't understand a word, I ute the context to gness its measing $\square$ Always $\square$ Sometames $\square$ Never

5. When you read do you guess what will be the main idea of the teat? $\square$ Always $\square$ Somatames $\square$ Never

6. When you read do you understand ideas before, during and at the end of a text
D Always
Sometimes:
$\square$ Never

7. When you read do you relate the stranoe with your own life?

$\square$ Always $\square$ Somenmes $\square$ Never

8. When you read are you able to anialyze and be critical?

Always Somatames

9. If 1 read mote in Enplish, will I lears more about this langage?

True

THANKS FOR YOUR HELP 